\title{
GENOPROTECTIVE EFFECTS OF ETHANOLIC STEM EXTRACTS OF TINOSPORA CORDIFOLIA ON SODIUM ARSENITE-INDUCED DNA DAMAGE IN SWISS MICE LYMPHOCYTES BY COMET ASSAY
}

\author{
AMBASTA SK ${ }^{1 *}$, SHASHIKANT ${ }^{2}$, SINHA UK ${ }^{1}$ \\ ${ }^{1}$ Department of Botany, Faculty of Science, Patna University, Patna, Bihar, India. ${ }^{2}$ Department of Biochemistry and Crop Physiology, Bihar \\ Agricultural College, Sabour, Bhagalpur, Bihar, India. Email: ambasta.2017@gmail.com
}

Received: 01 February 2019, Revised and Accepted: 09 April 2019

\section{ABSTRACT}

Objective: The study was aimed to evaluate the DNA protective effects of ethanolic extracts of Tinospora cordifolia stem on Swiss albino mice lymphocytes against the sodium arsenite-induced genotoxicity.

Methods: In this experiment, 25 animals of nearly the same age were equally divided. Group 1 (control) fed on tap water while rest four (2, 3, 4, and 5) groups were treated with $4 \mathrm{mg} / \mathrm{kg}$ body weight, per orally sodium arsenite for 12 weeks. Sodium arsenite pretreated groups (4 and 5) were followed by administration of $80 \mathrm{mg} / \mathrm{kg}$ body weight, per orally $T$. cordifolia extracts for the next 12 weeks. Animals were sacrificed at the $8^{\text {th }}$ week and $12^{\text {th }}$ week, respectively, for the assessment of sodium arsenite-induced genotoxicity and comparative genoprotective effects of experimental plant extracts. The extent of DNA migration is directly proportional to the magnitude of DNA damage. Percentage tail DNA content and olive tail moment parameters were used in the comet to relate DNA damage.

Results: The findings suggested that the ethanolic stem extracts of T. cordifolia significantly inhibited the sodium arsenite-induced oxidative genotoxicity. The phytoconstituents of T. cordifolia shown to retard genetic damage associated with arsenic exposure.

Conclusion: T. cordifolia may be used as a preventive herbal preparation against chemical or arsenical toxicity.

Keywords: Genoprotective, Genotoxicity, DNA migration, Oxidative stress.

(C) 2019 The Authors. Published by Innovare Academic Sciences Pvt Ltd. This is an open access article under the CC BY license (http://creativecommons. org/licenses/by/4. 0/) DOI: http://dx.doi.org/10.22159/ajpcr.2019.v12i5.31605

\section{INTRODUCTION}

Comet technique unlocks the mechanism of DNA damage including its repair while it is widely useful in biomonitoring and genotoxicity assessment [1]. Exogenous or endogenous mutagens cause oxidative damage to DNA molecule [2]. Genotoxins interact with DNA molecule which results in an alteration in number or structure of genes [3]. Comet assay involves insertion of cells in agarose and cells lysis by high salt concentration, followed by electrophoresis, which resulting comet tail from the deproteinized nuclei [4]. In genotoxicity study, comet assay is a standard method in vivo or in vitro system [5] because it is highly sensitive, simple, cheap, less time consuming and requires a little number of cells [6]. The comet image shows a distinct head (intact DNA) and a tail, which depicts the damaged or fragmented DNA [7].

Arsenic contaminated groundwater is probably the prime route of its exposure [8]. The trivalent form of arsenical enters the living beings mainly through diffusion while a little amount of pentavalent state passes the cell through active process $[9,10]$. Genotoxicity of arsenic is due to its ability to an alteration in methylation pattern of DNA, cell death induction or proliferation, inhibition of DNA repair enzyme cascades, and an induction of genomic damages $[11,12]$. Inorganic arsenic and its compounds may have the clastogenic effects [13] and it is a notorious Class I carcinogen for human beings [14]. Inorganic arsenic suppresses the expression of telomere length and may promote the necrotic activities as well as reactive oxygen species (ROS) production [15]. Hydroxyl radical is comparatively more dangerous species because it directly or indirectly attacks DNA molecule during the base excision repair mechanism and accelerates the single- or double-strand breakdown [16,17]. Arsenic hampers the DNA repair by the inhibition of ligation reaction or alteration in gene expression of DNA polymerase [18]. Suppression of the DNA repair system, an altered methylation pattern as well as glutathione level through ROS production, is a major cause of genotoxicity due to arsenical [19].

Tinospora cordifolia belongs to the family Menispermaceae and a precious plant in the Ayurveda or the traditional medicine system; it is large, glabrous, and deciduous climbing shrub [20]. Different class of phytochemicals such as alkaloids, diterpenoid lactones, glycosides, steroids, sesquiterpenoid, phenolic, aliphatic compounds, and polysaccharides has been isolated from T. cordifolia [21] while the stem is a rich source of steroids and contains $\beta$ - or $\delta$-sitosterol including hydroxyecdysone [22]. It exhibits various pharmacological activities such as anti-inflammatory, immunosuppressive, diuretic, antidiabetic, hepatoprotective, anticancer, and cholesterol lowering because it contains powerful antioxidant phytochemicals $[23,24]$.

In the present study, we examined the antigenotoxicity effects of ethanolic stem extracts of $T$. cordifolia on albino mice circulating blood lymphocytes using the comet assay against sodium arsenite-induced DNA damage.

\section{METHODS}

\section{Experimental animal}

Adult Swiss albino mice (28-32 g; 4 months age) were reared in the animal house of Mahavir Cancer Research Institute, Patna, India, for the present study. The experimental protocol was approved by the Institutional Animal Ethics Committee (2017/1B-10/08/17) of Mahavir Cancer Research Institute, Patna, India. The experiments were conducted under the most human effort to minimize threat or shock to the experimental animal. The animals were kept in polypropylene cages with a metal lid placed on top of the cage. To absorb waste and provide insulation, the cage was equipped with a layer of porous bedding composed of sawdust. They were allowed to acclimatize for 2 weeks under controlled conditions of alternate $12 \mathrm{~h}$ 
light/dark cycle and temperature $22-24^{\circ} \mathrm{C}$. The animals were maintained in the hygienic condition, and they had free access to food and water any time. They were allowed to feed on a healthy and nutritious diet.

\section{Chemicals}

Sodium arsenite (Sigma, chemical abstracts service [CAS]: 7784-46-5), ethidium bromide (Sigma, CAS: 1239-45-8), normal melting agarose (Biochem Life Sciences, CAS: 9012-36-5), low melting point agarose (Sigma, CAS: 9012-36-6), and Triton X-100 (HiMedia, CAS: 9002-93-1) were used. All chemicals used in this experiment of molecular grade were locally purchased from Bihar Scientific Chemicals, Ashok Raj Path, Patna, India.

\section{Extracts preparation of test plant material}

T. cordifolia plant was collected from the departmental glass house of botany and plant was identified and authenticated; a voucher specimen (TNB/60/2014) has been deposited in the Post Graduate Department of Botany, Patna University, Patna, Bihar, India, for future references. The departmental glass house is geographically located at the longitude of $85^{\circ} 10^{\prime} \mathrm{E}$ and latitude $25^{\circ} 36^{\prime} \mathrm{N}$. The stem ( $\left.100 \mathrm{~g}\right)$ of healthy T. cordifolia was first passed through the running tap water to remove grime and surface contaminates then allowed to dry for 15 days in hot air woven at $40^{\circ} \mathrm{C}$. The fine powder milled dried plant material was dissolved in $90 \%$ ethanol and for their complete dissolution; the resulting suspension was moved to the horizontal shaker for $24 \mathrm{~h}$. The separation of the extract was facilitated by vacuum rotavator (Buchi, R-3) at bath temperature $55^{\circ} \mathrm{C}$, rotation $6 \mathrm{rpm}$ and the pressure was maintained at 310 millibars. The extract was dried at room temperature by evaporation process and stored in the refrigerator at $4^{\circ} \mathrm{C}$ for the subsequent use.

\section{Herbal dose preparation of $\boldsymbol{T}$. cordifolia (stem) extracts}

The herbal dose was prepared by dilution of crude ethanolic stem extracts of T. cordifolia in 5\% ethanol, which was vigorously shaked for 2-3 min to their complete blending. To eliminate larger or coagulated particles of extracts, the suspension was filtered by $110 \mathrm{~nm}$ pore size Whatman filter paper 01 (Cat No: 1001110).

\section{Experimental design and animal grouping}

The 25 mice were divided equally into five groups. Animals were housed in a numerically marked cage. Animals of Group 1 (control) were received tap water supply of Patna city, India, while animals of Groups $2,3,4$, and 5 received sodium arsenite at the rate of $4 \mathrm{mg} / \mathrm{kg}$ body weight, per orally for 12 weeks. After completion of 12 weeks, Groups 4 and 5 (sodium arsenite pretreated group) were received $80 \mathrm{mg} / \mathrm{kg}$ body weight, per orally T. cordifolia stem ethanolic extract for the next 12 weeks. Animals were sacrificed at the $8^{\text {th }}$ week and $12^{\text {th }}$ week for evaluation of oxidative threat of DNA due to arsenite exposure as well as genoprotective effects of T. cordifolia stem extract in day's dependent manner. The doses were administered to the mice through the gavage method strictly with accordance of their body weight, daily once.

\section{Cell viability test}

Blood samples were obtained by puncture of the ocular artery of anesthetized mice, on the same day of the comet test. The blood was collected in vacutainer (BD, USA), internally coated with anticoagulant ethylenediaminetetraacetic acid (EDTA). To check photo-oxidation of genomic DNA, blood was protected from exposure of direct sunlight. Cell viability was evaluated by the trypan blue dye exclusion principle [25]. $0.4 \%$ trypan blue $(5 \mu \mathrm{l})$ was mixed with $10 \mu \mathrm{l}$ blood; resulting suspension was smeared on a glass slide and covered with a coverslip quickly. Approximately, a hundred cells of slides were focussed by a light microscope (Olympus, UK) at magnification (400X) for physical visualization of the number of stained or non-stained cells. The \% of viable cells was counted in haemocytometer by dividing the number of viable cells with the total number of cells and multiplied by 100 .

\section{Alkaline single-cell gel electrophoresis}

Comet assay was conducted as a three-layer procedure with slight modifications [7]. Among several versions of the comet assay, alkaline comet assay $(\mathrm{pH}>13)$ is superior for evaluating a broad spectrum of
DNA lesions or breaks because it enhances the sensitivity for detection of low levels of damage. Methanol surface sterilized glass slides (Blue star) of dimensions $75 \mathrm{~mm} \times 25 \mathrm{~mm} \times 1.35 \mathrm{~mm}$ with variation in thickness $\pm 0.1 \mathrm{~mm}$ were dipped ( $1 / 3$ frosted area) into $1 \%$ molten normal agarose. The slides were gently removed from agarose; undersides were wiped out and air dried up to the agarose solidification. $75 \mu \mathrm{l}(0.5 \%)$ low melting agarose dissolved in phosphate buffer solution was mixed with the $8 \mu$ l blood sample to form cell suspension for each slide. The cell suspension was a pipette onto agarose layer, spread by pressing the coverslip, kept on ice cooling packs for $10 \mathrm{~min}$ for their solidification. Coverslip was gently removed and $80 \mu \mathrm{l}$ of the third layer of low melting agarose was added with the pipette, immediately coverslip is placed, pressed with thumb, and allowed to solidify for $10 \mathrm{~min}$ on an ice pack. After removal of the coverslip, the slides were immersed in the freshly prepared cold lysing solution $(2.5 \mathrm{M} \mathrm{NaCl}, 100 \mathrm{mM}$ EDTA, $10 \mathrm{mM}$ Trizma, and $\mathrm{pH} 10.0$ ) with $1 \%$ Triton $\mathrm{X}-100$ for 120 min at $4^{\circ} \mathrm{C}$. Slides were washed 3-4 times with chilled distilled water to remove salt of the lysing solution. After lysis, slides were placed in horizontal gel electrophoresis tank (Fisher Biotech, FB-SB-1316) as close as possible and filled with cold freshly prepared electrophoresis solution $(1 \mathrm{mM}$ EDTA, $300 \mathrm{mM} \mathrm{NaOH}$, and pH 13.0) for 20 min incubation for expression of alkali-labile DNA damage sites. After incubation, the power supply of the electrophoresis chamber was turned on for 30 min with a setup of 300 milliamperes and 22 volt. After electrophoresis, slides were gently washed 3 times with a neutralization solution (0.4 M Trizma, pH 7.5) for $5 \mathrm{~min}$ for nullification of excess alkali. All procedural steps were performed under dim light conditions to minimize additional damage of DNA.

\section{Staining and examination of slides}

About $20 \mu \mathrm{l} \mathrm{of} 20 \mu \mathrm{g} / \mathrm{ml}$ ethidium bromide was added directly onto each slide in dropwise and allowed to left for $5 \mathrm{~min}$, which was followed by washing with cold water to remove excess of stain. Slides were wiped out underside and covered with a clean coverslip. Slides were studied using a fluorescent microscope (Nikon Ti-U inverted, Tokyo, Japan), attached with a charge-coupled device camera (DS-Qi2) having a NIS element software. The microscope was equipped with an excitation filter of $560 \mathrm{~nm}$ and a barrier filter of $590 \mathrm{~nm}$. Randomly approx. 40-50 lymphocytes were analyzed per slide at magnification $\times 200$ and the extent of DNA migration among the cells was compared among the different sample. Comet image was analyzed using Komet 5 software developed by Kinetic Imaging, Ltd. (Liverpool, UK). DNA damage was expressed as percentage tail DNA and olive tail moment (OTM), where percentage tail DNA $=($ Tail DNA $/[$ Tail DNA + Head DNA $]) \times 100$ and OTM = (Tail mean-Head mean $) \times$ Tail \% DNA/100. The comparatively higher value of percentage tail DNA and OTM indicates higher DNA damage [26].

\section{Statistical analysis}

Statistical analyses were carried out using GraphPad Prism for Window software, version 5.0. Differences between the groups were evaluated by one-way analysis of variance followed by paired t-test. Values were expressed as mean \pm standard deviation. Statistical significance was accepted at $\mathrm{p}<0.05$ level $[27,28]$.

\section{RESULTS}

The viability of lymphocytes was measured by means of trypan blue assay before conduction of comet assay and the percentage of viable cells was found $\geq 80$ (Fig. 1).

\section{DISCUSSION}

The results showed that sodium arsenite is genotoxic to rodents or mammalian cells and induces the DNA damage on its exposure. Sodium arsenite-treated animal was sacrificed at the $8^{\text {th }}$ week and $12^{\text {th }}$ week, depicted enhanced percentage tail DNA content and OTM values when the data were compared with control for their corresponding values, but such values fall down sharply after administration of test plant extracts in day's dependent fashion (Table 1). A graphical presentation 
Table 1: Mean values of a percentage tail DNA content and an olive tail moment of treated mice lymphocytes in comet analysis

\begin{tabular}{llll}
\hline Parameters of DNA damage & Treatment & $\mathbf{8}^{\text {th }}$ week $(\mathbf{m e a n} \pm$ SD) & $\mathbf{1 2}^{\text {th }}$ week (mean \pm SD) \\
\hline \% Tail DNA content & Tap water & $0.1417 \pm 0.1041$ & $0.1413 \pm 0.1039$ \\
& Sodium arsenite & $7.440 \pm 0.1217^{\mathrm{a}}$ & $10.21 \pm 0.500^{\mathrm{c}}$ \\
& T. cordifolia & $2.540 \pm 0.2000^{\mathrm{b}}$ & $0.040 \pm 0.0100^{\mathrm{d}}$ \\
Olive tail moment & Tap water & $0.070 \pm 0.0529$ & $0.073 \pm 0.053$ \\
& Sodium arsenite & $5.610 \pm 0.2000^{\mathrm{w}}$ & $22.77 \pm 1.120^{\mathrm{y}}$ \\
& T. cordifolia & $2.730 \pm 0.2000^{\mathrm{x}}$ & $0.013 \pm 0.0546^{\mathrm{z}}$ \\
\hline
\end{tabular}

SD: Standard deviation. T. cordifolia: Tinospora cordifolia. Results are mean of triplicate determinations. ${ }^{\mathrm{a} p} \leq 0.0001$ and ${ }^{\mathrm{c}} \mathrm{p} \leq 0.0001$ compared to the corresponding values for control animal (Group 1). ${ }^{b} \mathrm{p} \leq 0.0001$ and ${ }^{\mathrm{d}} \mathrm{p} \leq 0.0001$ compared to the corresponding values for the sodium arsenite-treated group animals. ${ }^{\mathrm{w}} \mathrm{p} \leq 0.0001$ and ${ }^{\mathrm{y}} \mathrm{p} \leq 0.0001$ compared to the corresponding values for control animal (Group 1). ${ }^{\mathrm{x}} \mathrm{p} \leq 0.0001$ and ${ }^{\mathrm{z}} \mathrm{p} \leq 0.0001$ compared to the corresponding values for the sodium arsenite-treated group animals

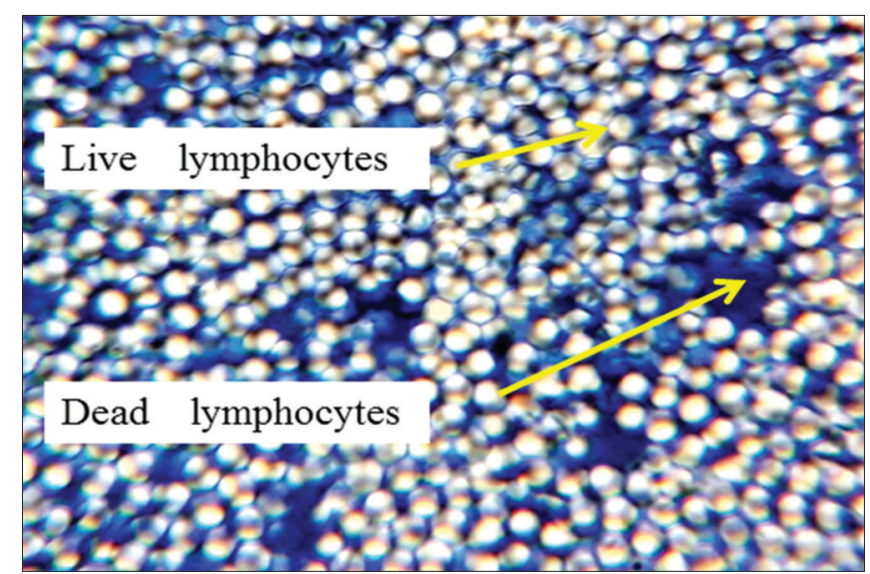

Fig. 1: Viable and dead lymphocyte stained with trypan blue dye (400 x). Cells were counted using hemocytometer. The experiment was run in triplicate

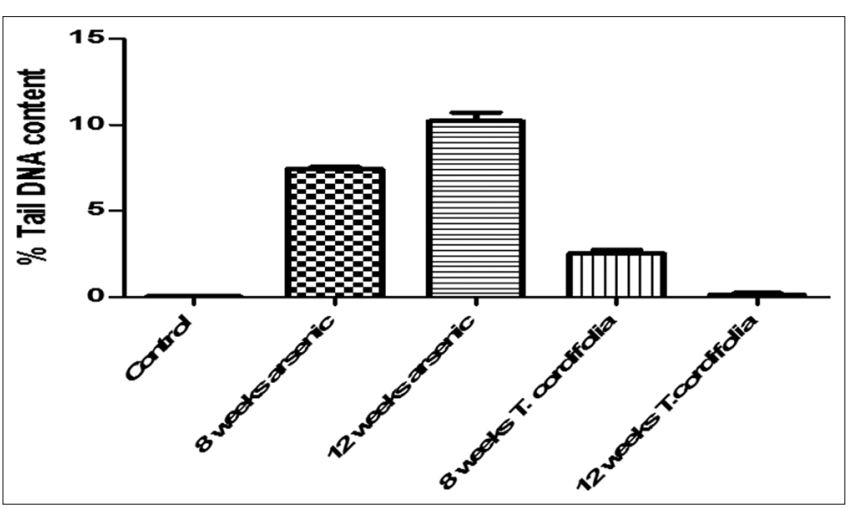

Fig. 2: Antigenotoxic effects of Tinospora cordifolia extract on sodium arsenite-induced DNA damage in lymphocytes, expressed as a percentage of DNA in the tail. Each bar represents the results

in terms of mean \pm standard deviation. Analysis of variance, $\mathbf{p}<0.05$

has shown the reduction in percentage tail DNA after administration of T. cordifolia extract (Fig. 2). Similarly, arsenite exposed animal groups sacrificed at the $8^{\text {th }}$ week and $12^{\text {th }}$ week, showed an increase in OTM values, but a sharp decrease in OTM values was observed after T. cordifolia administration (Fig. 3). The random microphotographs captured during the study showed that DNA migration increased in sodium arsenite exposed group, but after administration of the test plant ethanolic extract, DNA migration decreased surprisingly (Fig. 4). Arsenic and its compounds introduce oxidative damage or stress which may cause an alteration in the antioxidant defense system [29,30]. Many ailments including DNA damage, cancer development, and degeneration of cellular envelop may be caused due to oxidative stress [31]. Arsenicals probably replace phosphorous group from the backbone of DNA moiety

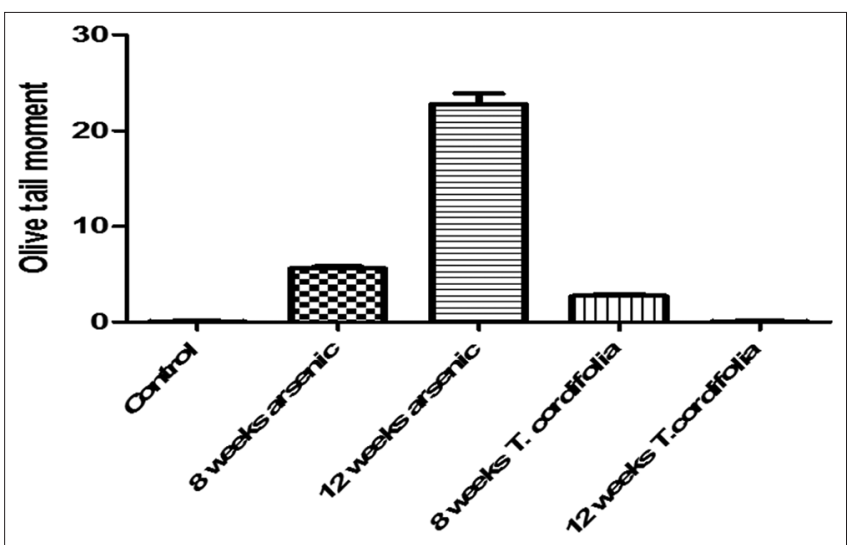

Fig. 3: Protective effects of Tinospora cordifolia ethanolic extract on sodium arsenite-induced oxidative DNA damage in lymphocytes, expressed as an olive tail moment. Each bar represents the results in terms of mean \pm standard deviation. Analysis of variance, $\mathrm{p}<0.05$

and form the arsenodiester bond which may be the major cause of clastogenicity or chromosomal fragmentation [32]. $\mathrm{NaAsO}_{2}$ may cause mutagenicity and carcinogenicity and dose-dependent enhancement of ROS which leads to DNA damage, chromosomal breakages, and cell transformation [33].

It was reported that alkaloids of T. cordifolia augmented the antioxidant molecules synthesis on exposure of xenobiotic compounds [34]. Secondary derivatives or metabolites of medicinal plants such as terpenoids, alkaloids, and flavonoids actively participate in the remedies of the several diseases [35]. Flavonoids can modulate the antioxidant enzymes activity as well as inhibit the cell proliferation because it scavenges the free radicals [36]. T. cordifolia ethanolic extract possesses the metal chelating property so it has reducing power against the free radicals [37]. Medicinal plants may attribute lots of pharmacological activities such as antiviral, anticancer, antifungal, antioxidant, and antiparasitic [38,39], and rarely, it possesses toxic alkaloids, phorbol ester, or other toxic metabolites [40]. T. cordifolia extract may facilitate significant protection against the oxidative damage of biomolecules such as proteins, DNA, and lipids [41]. Alcoholic extract of this plant showed the antineoplastic and antioxidant properties [42]. It is evident that ethanolic extracts of medicinal plants may be useful in preventing the deleterious effects of oxidative stress caused by arsenicals [43]. T. cordifolia has the capability of curing a lot of diseases in the modern system of medicine [44] and such plant showed the antioxidative and amelioration effect on cyclophosphamide-induced toxicity [45]. Such shrubs probably protect the DNA damage against radiations through several mechanisms including free radicals scavenging, inhibition of free radicals chain reaction, and repair of DNA and cell membrane [46]. Several studies have been conducted on T. cordifolia efficacy on antioxidant and anticancer activities [47] and in monomethyl sulfonate treated mice; it repairs the DNA damage and reduces the micronucleus 


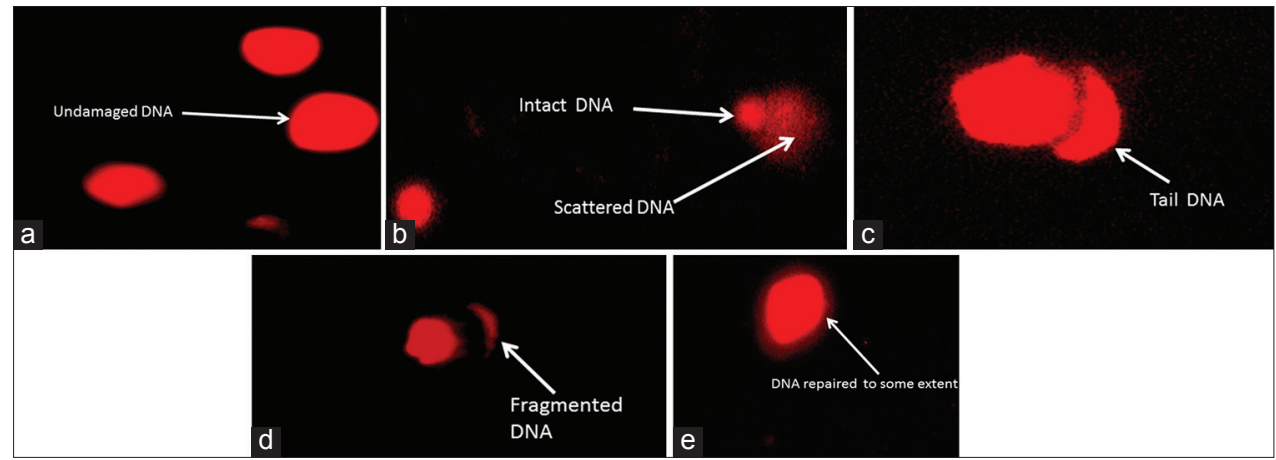

Fig. 4: Images of single cell electrophoresis of lymphocytes showing arsenite-induced DNA damage and its reduction by Tinospora cordifolia (a) control; (b-d) treated with sodium arsenite; (e) treated with T. cordifolia

counts probably due to its antigenotoxic potenza [48]. The probable mode of action may be due to binding of bioactive molecules of T. cordifolia to the nucleophilic sites of DNA; hence, mutagen is unable to attack or bind to the theses site [49]. The protective efficacy of natural antioxidants is higher than the laboratory synthesized antioxidants due to relatively more bioavailability of antioxidants from the natural plant sources [50]. It was reported that secondary metabolites obtained from T. cordifolia work against the four different cancer cell lines [51]; in addition to these, it may be antimutagenic and effective against various virus-related diseases including HIV [52].

\section{CONCLUSION}

The ethanolic stem extracts of $T$. cordifolia possess the antioxidant activity against the sodium arsenite-induced genotoxicity. Such plant may protect the DNA through free radical scavenging, termination of free radical chain reactions mechanisms and promote the DNA repairs through activation of DNA repair enzyme cascades.

\section{ACKNOWLEDGMENT}

The study was financially supported by the Department of Science and Technology, Government of India, under project DBT-PU-IPLS, Sanction No: BT/PR4577/INF/22/149/2012.

\section{AUTHORS' CONTRIBUTIONS}

All authors had equally contributed to the design of the research protocol and writing of the manuscript.

\section{CONFLICTS OF INTEREST}

The authors have declared no conflicts of interest.

\section{REFERENCES}

1. Collins AR. The comet assay: A heavenly method. Mutagenesis 2015;30:1-4

2. Azqueta A, Slyskova J, Langie SA, Gaivão IO, Collins A. Comet assay to measure DNA repair: Approach and applications. Front Genet 2014;5:1-8.

3. Maurici D, Aardema M, Corvi R, Kleber M, Krul C, Laurent C, et al. Genotoxicty and mutagenicity. Altern Lab Anim 2005;1:117-30.

4. Enciso M, Sarasa J, Agarwal A, Fernández JL, Gosálvez J. A twotailed comet assay for assessing DNA damage in spermatozoa. Reprod Biomed Online 2009;18:609-16.

5. Lapuente J, Lourenço J, Mendo SA, Borràs M, Martins MG, Costa PM, et al. The comet assay and its applications in the field of ecotoxicology: A mature tool that continues to expand its perspectives. Front Genet 2015;6:1-20.

6. Collins AR. The comet assay for DNA damage and repair: Principle, applications, and limitations. Mol Biotechnol 2004;26:249-61.

7. Liao W, McNutt MA, Zhu WG. The comet assay: A sensitive method for detecting DNA damage in individual cells. Methods 2009;48:46-53.

8. Kapaj S, Peterson H, Liber K, Bhattacharya P. Human health effects from chronic arsenic poisoning-a review. J Environ Sci Health A Tox Hazard Subst Environ Eng 2006;41:2399-428.
9. Cohen SM, Arnold LL, Eldan M, Lewis AS, Beck BD. Methylated arsenicals: The implications of metabolism and carcinogenicity studies in rodents to human risk assessment. Crit Rev Toxicol 2006;36:99-133.

10. Jomova K, Jenisova Z, Feszterova M, Baros S, Liska J, Hudecova D, et al. Arsenic: Toxicity, oxidative stress and human disease. J Appl Toxicol 2011;31:95-107.

11. Kitchin KT. Recent advances in arsenic carcinogenesis: Modes of action, animal model systems and methylated arsenic metabolites. Toxicol Appl Pharmacol 2001;172:249-61.

12. Kligerman $A D$, Tennant $A H$. Insights into the carcinogenic mode of action of arsenic. Toxicol Appl Pharmacol 2007;222:281-8.

13. Majumdar KK. Arsenicosis and cancer: A perspective. Discov Biol 2015;1:1-4.

14. Faita F, Cori L, Bianchi F, Andreassi MG. Arsenic-induced genotoxicity and genetic susceptibility to arsenic-related pathologies. Int J Environ Res Public Health 2013;10:1527-46.

15. Ferrario D, Collotta A, Carfi M, Bowe G, Vahter M, Hartung T, et al. Arsenic induces telomerase expression and maintains telomere length in human cord blood cells. Toxicology 2009;260:132-41.

16. Flora SJ, Bhaduaria S, Kannan GM, Singh N. Arsenic induced oxidative stress and role of antioxidant supplementation during chelation: A review. J Environ Biol 2007;28:333-47.

17. Mourón SA, Grillo CA, Dulout FN, Golijow CD. Induction of DNA strand breaks, DNA-protein cross links and sister chromatid exchanges by arsenite in a human lung cell line. Toxicol In Vitro 2006;20:279-85.

18. Bustaffa E, Stoccoro A, Bianchi F, Migliore L. Genotoxic and epigenetic mechanism in arsenic carcinogenicity. Arch Toxicol 2014;88:1043-67.

19. Kousar S, Javed M. Assessment of DNA damage in peripheral blood erythrocytes of fish exposed to arsenic under laboratory conditions. Int J Curr Microbial Appl Sci 2015;3:877-88.

20. Mittal J, Sharma MM, Batra A. T. cordifolia: A multipurpose medicinal plant-a review. J Med Plants Stud 2014;2:32-47.

21. Singh SS, Pandey SC, Srivastava S, Gupta VS, Patro B, Ghosh AC. Chemistry and medicinal properties of Tinopora cordifolia (Guduchi). Indian J Pharmacol 2003;35:83-91.

22. Sudhakar C, Joshi LK, Sehgal A. Assessment of antioxidant and antilipid peroxidation capability of Guduchi (T. cordifolia). Res J Pharm Biol Chem Sci 2015;6:458-63.

23. Bala M, Gupta GL. Hepato and nephro-protective effects of Tinospora cordifolia against sodium nitrite induced oxidative stress. Indo Am J Pharm Res 2016;6:4102-10.

24. Verma R, Chaudhary HS, Agrawal RC. Evaluation of anticarcinogenic and antimutagenic effect of Tinospora cordifolia in experimental animals. J Chem Pharm Res 2011;3:877-81

25. Ahmed MK, Hossain MA, Arif M, Perwin E, Khan MS, Islam MM. Assessing the genotoxic potential of arsenic in tilapia using alkaline comet assay and micronucleus test. Chemosphere 2011;84:143-9.

26. Behravan J, Mosafa F, Soudmand N, Taghiabadi E, Razavi BM, Karimi G. Protective effects of aqueous and ethanolic extracts of Portulaca oleracea L. Aerial parts on $\mathrm{H}_{2} \mathrm{O}_{2}$ - induced DNA damage in lymphocytes by comet assay. J Acupunct Meridian Stud 2011;4:193-7.

27. Mozaffarich M, Schoetzau A, Sauter M, Grieshaber M, Orgul S, Chaja OG, et al. Comet assay analysis of single stranded DNA breaks in circulating leucocytes of glaucoma patients. Mol Vis 2008;14:1584-8.

28. Kumaravel TS, Vilhar B, Faux SP, Jha AN. Comet assay measurements: A perspective. Cell Biol Toxicol 2009;25:53-64.

29. Liu SX, Athar M, Lippai I, Waldren C, Hei TK. Induction of oxygen radicals by arsenic: Implications for mechanism of genotoxicity. Proc 
Natl Acad Sci USA 2001;98:1643-8.

30. Wang TS, Huang H. Active oxygen species are arsenic affect oxidative system in pig 733 involved in the induction of micronuclei in XRS5 cells. Mutagenesis 1994;9:253-7.

31. Balakrishnan BB, Krishnasamy K. Evaluation of free radical screening and antioxidants potential of Moring a concanensis nimmo- a medicinal plant used in Indian traditional medication system. Int J Pharm Pharm Sci 2018;10:91-7.

32. Mandal BK, Suzuki KT. Arsenic round the world: A review. Talanta 2002;58:201-35.

33. Zhang Z, Wang X, Cheng S, Sun L, Son YO, Yao H, et al. Reactive oxygen species mediate arsenic induced cell transformation and tumorigenesis through Wnt/beta -catenin pathway in human colorectal adenocarcinoma DLD1 cells. Toxicol Appl Pharmacol 2011;256:114-21.

34. Singh RP, Banerjee S, Kumar PV, Raveesha KA, Rao AR. Tinospora cordifolia induces enzymes of carcinogen/drug metabolism and antioxidant system and inhibits lipid peroxidation in mice. Phytomedicine 2006; 13:74-84

35. Nwachukwu CU, Umeh CN, Kalu IG, Slyvester O, Magnus CN. Identification and traditional uses of some common medicinal plants in Ezinihitte Mbaise LGA of Imo state, Nigeria. Rep Opin 2010;2:1-8.

36. Mohanapriya M, Ramaswamy L, Rajendran R. Health and medicinal properties of lemon (Citrus limonum). Int J Ayurvedic Herb Med 2013;3:1095-100.

37. Bhawya D, Anilakumar KR. In vitro antioxidant potency of Tinospora cordifolia (gulancha) in sequential extracts. Int J Pharm Biol Arch 2010;1:448-56.

38. Kapkoti B, Lodhiyal N, lodhiyal LS. Ethno-medicinal plants and their use by van panchayat people in Nainital of Kumaun region, Uttrakhand. Biolife 2014;2:526-32.

39. Jiofack T, Fokunang $\mathrm{C}$, Guedje $\mathrm{N}$, Kemeuze V, Fongnzossie E, Nkongmeneck BA, et al. Ethnobotanical uses of medicinal plants of two ecological regions of Cameroon. Int J Med Med Sci 2010;2:60-79.

40. Wink M. Modes of action of herbal medicines and plants secondary metabolites. Medicines 2015;2:251-86.

41. Ilaiyaraja N, Khanum F. Antioxidant potential of Tinospora cordifolia extract and their protective effect on oxidation of biomolecules.
Pharmacogn J 2011;3:56-62.

42. Pandey P, Mehta A, Hajra S, John J, Mehta P. Antioxidant property, total phenolic content and inhibition of $\alpha$-amylase activity of Ruta graveolens L. Leaves extract. J Pharmacol Res 2011;4:1735-7.

43. Aqil F, Ahmed I, Mehmood Z. Antioxidant and free radical scavenging properties of twelve traditionally used Indian medicinal plants. Turk J Biol 2006:30:177-83.

44. Srivastava P. Tinospora cordifolia (Amrita) - a miracle herb and lifeline too many diseases. Int J Med Aromat Plants 2011;1:57-61.

45. Mathew S, Kuttan G. Antioxidant activity of Tinospora cordifolia and its usefulness in the amelioration of cyclophosphamide induced toxicity. J Exp Clin Cancer Res 1997;16:407-11.

46. Goel HC, Prasad J, Singh S, Sagar RK, Agrawal PK, Bala M, et al. Radio protective potential of an herbal extract of Tinospora cordifolia. J Radiat Res 2004:45:57-64.

47. Panares KA, Abamo F, Billacura M. Genotoxic, anti-genotoxic and protective evaluation of Tinospora cordifolia stem by peripheral blood micronucleus assay. Sci Int 2017;29:97-101.

48. Kumar M, Maneemegalai S. Evaluation of larvicidal effect of Lantana camara Linn. Against mosquito species Aedes aegypti and Culex quinquefasciatus. Adv Biol Res 2008;2:39-43.

49. Premkumar A, Kreitman RJ, Kindler H, Willingham MC, Pastan I. Phase I study of SS1P, a recombinant anti-mesothelin immunotoxin given as a bolus I.V infusion to patients with mesothelin-expressing mesothelioma, ovarian, and pancreatic cancers. Clin Cancer 2004;13:5144-9.

50. Meziti A, Bouriche H, Hichem M, Kada S, Senator A, Dimertas I. Antioxidant and anti-inflammatory activities of Rubus fruticosus and Zizyphus vulgaris methanol extracts. Int J Pharm Pharm Sci 2017;9:69-76.

51. Bala M, Pratap K, Verma PK, Singh B, Padwad Y. Validation of ethno medicinal potential of Tinospora cordifolia for anticancer and immunomodulatory activities and quantification of bioactive molecules by HPTLC. J Ethnopharmacol 2015;175:131-7.

52. Sharma U, Bala M, Kumar P, Rampal G, Kumar N, Singh B, et al. Antimutagenic extract from Tinospora cordifolia and its chemical composition. J Med Plants Res 2010;4:2488-94. 